\title{
EFFECT OF HOT DRYING ON THE ESSENTIAL OIL CONTENT AND COLOUR CHARACTIRISTICS OF PEPPERMINT (Mentha piperita)
}

\author{
Nguyen Thi Kim Chi, Duong Thi Thanh Thao, Hoang Quoc Tuan* \\ Hanoi University of Science and Technology, School of Biotechnology and Food technology, \\ Department of Quality management, No 1 Dai Co Viet Street, Hanoi, Vietnam \\ "Email: tuanhqibft@gmail.com; tuan.hoangquoc@hust.edu.vn
}

Receipted: $28^{\text {th }}$ August 2015; Accepted for publication: 29 March 2016

\begin{abstract}
The main objectives of this study were to investigate the effect of different temperature of hot air drying on the qualities of dried peppermint, including essential oil content, colour parameters, and visual sensory quality and to develop mathematical models for the colour change kinetics. The drying experiments were carried out at five air temperatures, 40, 50, 60, 70 and $80{ }^{\circ} \mathrm{C}$. The colour parameters for colour change of the materials were quantified by the Hunter $L$ (whiteness/darkness), $a$ (redness/greenness) and $b$ (yellowness/blueness) system. These values were also used for calculation of total change $(\Delta E)$ as well as chroma, hue angle and Browning index. A consumer preference test was conducted with 80 consumers to assess the colour quality of 05 dried peppermint samples. The results showed that the decrease in essential oils content at high drying temperature is higher than at low temperature. Least Squares regression was used to determine the relationship between the visual sensory scores of consumer taster and the Hunter L.a.b values. It was observed that $L, a, \Delta E$ and hue angle values were fitted to the zero-order model, while $b$ and chroma were fitted to the first-order model.
\end{abstract}

Keywords: peppermint, colour, drying kinetic colour model.

\section{INTRODUCTION}

Peppermint (Mentha piperita) is a popular herb that can be used in numerous forms (i.e., oil, leaf, leaf extract, and leaf water). This herbal preparation is used in cosmetics, personal hygiene products, foods, teas and pharmaceutical products for both its flavouring and fragrance properties [1]. Peppermint, like many other herbs, is highly seasonal in nature. In order to preserve this seasonal and highly perishable plant and make them available to consumers all year round at low prices, it is subjected to post harvest technological treatments such as drying and freezing [2]. Drying is one of the oldest preservation techniques. Natural drying, under open sun or in the shade, and hot air drying are still most known and widely used methods of drying. Availability of sun being very much uncertain, sun drying is not effective in some region. Besides, there are other problems in sun drying due to the slowness of the process and the 
exposure to the environment, the product gets contaminated from dust, insects etc. The weather being moist round the year, spoilage takes place very soon. Therefore, more rapid, safe and controllable drying methods are required. The forced convection hot air drying is an effective method to rapidly produce a uniform, hygienic product with attractive colours. Therefore, a forced convective cabinet dryer has been developed to address such problem [3]. However, the colour and chemical composition of herb products could be affected by hot temperature during drying. Besides the chemical composition, the colour also significantly affects the sensory quality of products. Hence, it is crucial to determine and control the colour and chemical composition of the processed peppermint. The changes of colour can be related with the degradation of nutritional compounds during processing that have important bioactive properties [2]. Standardized instrumental colour measurements give us objective parameters that can be used as quality index for raw and processed foods. They can also be used for the determination of conformity of food quality to specification and for the analysis of quality changes as a result of food processing, storage and other factors. Several colour scales have been used to describe colour, those most used in food industry are the Hunter colour $L, a, b$ CIE system and the Munsell colour solid [4]. Maintaining the natural colour in processed and stored foods has been a major challenge in food processing. Most studies on changes in colour due to time and temperature treatments during food processing such as drying, heating, etc. There are numerous publications on the kinetics of colour change of food material. The majority of these works report zero order (eq.1) or first order (eq.2) degradation reaction kinetics [5 - 7].

$$
\begin{aligned}
& \mathrm{C}=\mathrm{C}_{\mathrm{o}} \pm \mathrm{k}_{\mathrm{o}} \mathrm{t} \\
& \mathrm{C}=\mathrm{C}_{\mathrm{o}} \exp \left( \pm \mathrm{k}_{1} \mathrm{t}\right)
\end{aligned}
$$

where $\mathrm{C}$ is the measured value of colour variable at time $t$, Co the initial value of colour variable at time zero, $\mathrm{t}$ the drying time $(\mathrm{min})$, ko the zero-order kinetic constant $\left(\mathrm{mim}^{-1}\right)$ and $\mathrm{k} 1$ is the first-order kinetic constant $\left(\mathrm{min}^{-1}\right) ;(+)$ and (-) indicate formation and degradation of quality parameter, respectively.

To the best of our knowledge, no significant research on the change of essential oil content and kinetics model for colour change of peppermint during hot air drying as well as the relation between colour and sensory evaluation has been reported in the literature. Therefore, the objectives of the present work are to study the effect of hot drying temperature on essential oil contents and colour change kinetics and to find the relation between colour of dried peppermint leaves and sensory quality in order to predict the quality of peppermint including essential oil contents and colour changes with time by foregoing drying techniques.

\section{MATERIALS AND METHODS}

\subsection{Materials}

The fresh peppermints were purchased in a local market in Hanoi. Prior to each of drying experiments, the leaves were separated from stems. The moisture content of each sample was measured individually. The experiment was operated at temperatures of $40{ }^{\circ} \mathrm{C}, 50{ }^{\circ} \mathrm{C}, 60{ }^{\circ} \mathrm{C}$, $70{ }^{\circ} \mathrm{C}$ and $80{ }^{\circ} \mathrm{C}$, and the air velocity fixed at $1.3 \mathrm{~m} / \mathrm{s}$. The drying process is stopped when the moisture content of the sample reached $8.1-9.3 \%$ (dry basis). The drying experiments are replicated three times for each temperature and the average values are taken.

\subsection{Color measurements}


Sample colour was measured before drying and at pre-specified time interval during drying period by Hunter-Lab ColorFlex, A60-1010-615 model colormeter. This system uses three values ( $\mathrm{L}, \mathrm{a}$ and $\mathrm{b}$ ) to describle the precise location of a colour inside a three-dimensional visible colour space. The colorimeter was calibrated against standard white and green plates before each actual colour measurement. For each sample at least five measurements were performed at different positions and the mean values was used. The measurements were displayed in L, a and $\mathrm{b}$ values which represent light-dark spectrum with a range from 0 (black) to 100 (white), the green - red spectrum with a range from -60 (green) to +60 (red) and the blue-yellow spectrum with a range from -60 (blue) to +60 (yellow) dimensions repestively.

Total colour difference was calculated using following equation, where subscript " 0 " refers to colour reading of peppermint leaves. Fresh peppermint leaves was used as the reference and a larger $\Delta \mathrm{E}$ means a greater colour change compared to the reference material.

$$
\begin{aligned}
& \Delta E=\sqrt{\left(L_{0}-L\right)^{2}+\left(a_{0}-a\right)^{2}+\left(b_{0}-b\right)^{2}} \\
& \text { Chroma }=\left(\mathrm{a}^{2}+\mathrm{b}^{2}\right)^{0.5} \\
& \text { Hue Angle }=\tan ^{-1}(\mathrm{~b} / \mathrm{a})
\end{aligned}
$$

where $\mathrm{L}$ is degree of lightness to darkness, $\mathrm{L}_{0}$ is initial value of $\mathrm{L}$, a is degree of redness to greennes, $a_{0}$ is initial value of $a, b$ is degree of yellowness to blueness and $b_{0}$ is initial value of $b$ [4].

\subsection{Essential Oil extraction}

Essential oil was extracted from $200 \mathrm{~g}$ of leaves by steam distillation for $1 \mathrm{~h}$ using a $1 \mathrm{~L}$ Clevenger apparatus. The essential oil yield was calculated as the volume ( $\mathrm{ml})$ of oil per weight of samples [8].

\subsection{Consumer test}

A consumer preference test was conducted with 80 consumers to assess the colour quality of 05 dried peppermint powders. Consumers were recruited from Hanoi, Vietnam and age between 18 and 50. A 5-point hedonic scale ranging from $1=$ dislike it very much to $5=$ like it very much was used to evaluate acceptance from the dried peppermint samples for the attributes of colour.

\subsection{Statistical analysis}

Statistical comparisons of the mean values for each experiment were performed by oneway analysis of variance (ANOVA), followed by the general linear model with repeated measures defined factors using SPSS 22 for Windows software. Significance was declared at P $\leq$ 0.05. PLS regression was performed by XLSTAT (version, 2014).

\section{RESULTS AND DISCUSSION}

\subsection{Effect of drying air temperature on essential oil content}


The fresh and dried peppermint leaves were analyzed for essential oil content. Results are shown in Table 1. The fresh peppermint leaves afforded about $1.6 \mathrm{ml}$ essential oil per $200 \mathrm{~g}$ samples. The essential oil of fresh peppermint in this study was more or less similar to those reported by several previous studies [8 - 10].

Table 1. Essential oil content of fresh peppermint leaves and dried peppermint leaves at different drying air temperature.

\begin{tabular}{cccc}
\hline Samples & $\begin{array}{c}\text { Weight of samples } \\
(\mathbf{g})\end{array}$ & $\begin{array}{c}\text { Drying time } \\
(\text { minutes })\end{array}$ & $\begin{array}{c}\text { Essential oil } \\
\text { content }(\mathbf{m l})\end{array}$ \\
\hline Fresh leaves & $200 \pm 1.45$ & 0 & $1.6 \pm 0.54$ \\
Dried at $40^{\circ} \mathrm{C}$ & $200 \pm 1.22$ & $360 \pm 5$ & $1.5 \pm 0.47$ \\
Dried at $50^{\circ} \mathrm{C}$ & $200 \pm 1.08$ & $120 \pm 5$ & $1.5 \pm 0.35$ \\
Dried at $60^{\circ} \mathrm{C}$ & $200 \pm 1.18$ & $90 \pm 5$ & $1.4 \pm 0.42$ \\
Dried at $70^{\circ} \mathrm{C}$ & $200 \pm 1.32$ & $60 \pm 5$ & $1.2 \pm 0.31$ \\
Dried at $80^{\circ} \mathrm{C}$ & $200 \pm 1.28$ & $40 \pm 5$ & $0.9 \pm 0.11$ \\
\hline
\end{tabular}

It was observed generally that the decrease of essential oils content at hight drying temperature is higher than at lower temperature. However, the decrease of essential oil content is not significant among samples dried at 40,50 and $60{ }^{\circ} \mathrm{C}$. Therefore, to save energy, drying at 50 or $60{ }^{\circ} \mathrm{C}$ should be chosen due to shorter drying time. These results showed that temperature significantly affects the qualities of dried peppermint.

\subsection{Colour and sensory evaluation of dried peppermints.}

Consumer preference test conducted with 80 consumers evaluating five dried peppermint products showed that the product which was dried at $50{ }^{\circ} \mathrm{C}$ was the most preferable (mean 4.76), followed by sample dried at $40{ }^{\circ} \mathrm{C}$ (mean 4.42 ), $60{ }^{\circ} \mathrm{C}$ (mean 3.42), $70{ }^{\circ} \mathrm{C}$ (mean 2.58) and $80{ }^{\circ} \mathrm{C}$ (mean 2.24) $(\mathrm{p} \leq 0.05)$ (Fig. 1). The significant differences observed in the colour evaluations indicate that the set provides a reasonable basis for the evaluation of possible relationship between three values ( $L, a$ and $b$ ) and colour characteristics and/or colour evaluations.

Based on the Hunter colour parameters which were analyzed by Hunter-Lab ColorFlex and preference scores of 05 dried peppermint products, the results of PLSR analysis indicated the positive and negative correlations between Hunter colour parameter and specific sensory attributes. The validation coefficients of three colour values for which regression models were developed as listed in Table 2. In that, both the weight vectors of a values was positive correlated with sensory attributes (colour quality), while the others have negatively or positively correlated (Fig. 2 and Fig. 3).

When considering the calibration sets, a good correlation between three values ( $L, a$ and $b)$ and colour quality ranking could be achieved as observed from a good determination coefficient $\left(\mathrm{R}^{2}\right)$ of 0.976 . The error rate of predictability of calibration model could be expressed from a term of root mean square error of estimation (RMSE), which was found at 0.24. The good correlation of the reliable calibration model suggested that the complexity of sensory perception could be related directly to the three values ( $L, a$ and $b$ ) by means of multivariate analysis. The low RMSE values of this model suggested that three values $(L, a$ and $b)$ obtained from 
instrument methods provided sufficient correlation information to the colour sensory quality ranking.

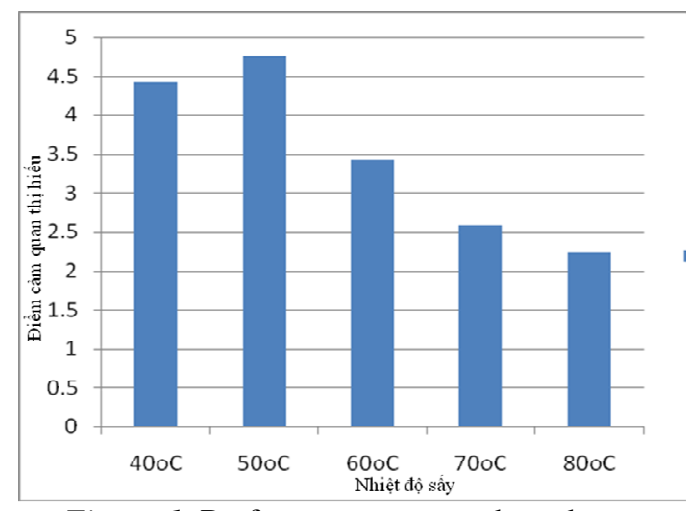

Figure 1. Preference scores and products.

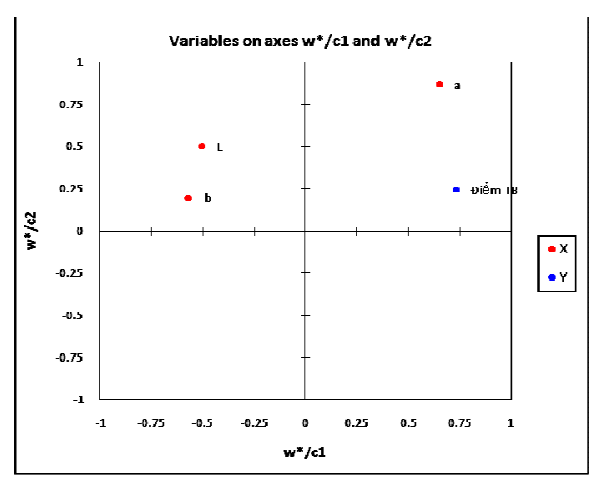

Figure 2. Consumer preference (Y) and Hunter colour parameter $(\mathrm{X})$ of dried peppermint.

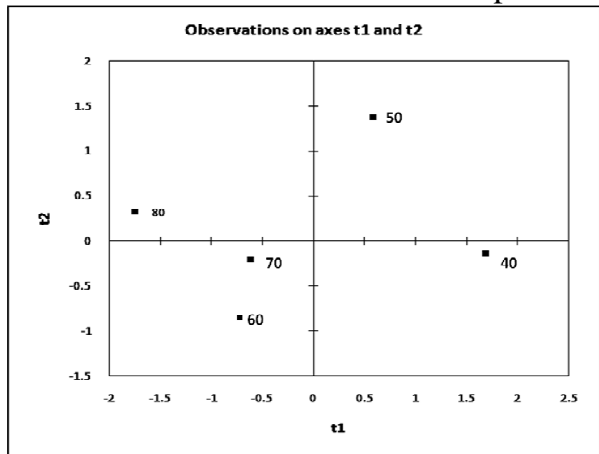

Figure 3. The correlations map on $\mathrm{t} 1$ and $\mathrm{t} 2$ of products (obs), Hunter colour parameter $(\mathrm{X})$ and consumer preference $(\mathrm{Y})$.

Furthermore, compounds with high relevance for explaining dependent Y-variables were also identified from variable importance in the projection values (VIP). Large VIP values, more than 0.8 , are the most relevant for explaining the colour quality rankings of dried peppermint and the compounds with VIP values greater than 0.8 were presented in Table 3 . It was found that key values contributing to the construction of the colour quality predictive model were composed of various Hunter colour parameter.

Table 2. Correlation matrix of the variables (correlation matrix of $\mathrm{W}$ ).

\begin{tabular}{ccc}
\hline Variable & $\mathrm{w}^{* 1} 1$ & $\mathrm{w}^{* 2}$ \\
\hline $\mathrm{L}$ & -0.6017 & 0.6011 \\
$\mathrm{a}$ & 0.5002 & 0.7108 \\
$\mathrm{~b}$ & -0.5770 & 0.2163 \\
\hline
\end{tabular}

Table 3. Key values contributing to the construction of predictive model using Hunter colour parameter.

\begin{tabular}{ccc}
\hline Variable & VIP & $\begin{array}{c}\text { Standardized } \\
\text { coefficients }\end{array}$ \\
\hline $\mathrm{a}$ & 1.1342 & 0.6487 \\
$\mathrm{~b}$ & 0.9762 & -0.4407 \\
$\mathrm{~L}$ & 0.8908 & -0.3163 \\
\hline
\end{tabular}

VIP: Variable Importance in the Projection 
All VIP values are higher than 0.8 , therefore a simplified model of favourable products was obtained (Eq.6).

$$
\mathrm{Y}=0.6487 * \mathrm{a}-0.4407 * \mathrm{~b}-0.3163 * \mathrm{~L}
$$

Equation of the model of favourable products showed that all there colour values could significantly affect colour quality ranking of dried peppermint. According to this equation, variable " $L$ " and " $b$ " contribute to a decrease while variable " $a$ " contributes to an increase of the colour quality of dried peppermint products.

\subsection{Colour change kinetic models for the drying process of peppermint}

To investigate the effect of hot air on colour change kinetics of peppermint leaves during drying processing, air temperature of $50{ }^{\circ} \mathrm{C}$ was used for drying of constants amount of $500 \mathrm{~g}$ peppermint leaves. The values of $\mathrm{L}, \mathrm{a}, \mathrm{b}$ and total colour change $(\Delta \mathrm{E})$ obtained from the experimental data during hot air drying and model data are presented in Table 3.

Table 3. Variation of $L, a$ and $b$ values as function of drying time at $50{ }^{\circ} \mathrm{C}$.

\begin{tabular}{ccccccc}
\hline \multirow{2}{*}{$\begin{array}{c}\text { Time } \\
\text { (minutes) }\end{array}$} & \multicolumn{3}{c}{ Hunter colour parameter } & \multirow{2}{*}{$(\Delta \mathbf{E})$} & Chroma & Hue Angle \\
\cline { 2 - 4 } & $\mathbf{L}$ & $\mathbf{a}$ & $\mathbf{b}$ & & & \\
\hline 0 & $43.37 \pm 1.45$ & $-7.22 \pm 0.25$ & $21.48 \pm 1.07$ & & $22.66 \pm 1.02$ & $108.58 \pm 1.06$ \\
20 & $39.66 \pm 1.64$ & $-6.37 \pm 0.16$ & $19.97 \pm 1.37$ & $4.10 \pm 0.51$ & $20.96 \pm 1.11$ & $107.70 \pm 1.03$ \\
40 & $36.66 \pm 1.60$ & $-5.79 \pm 0.11$ & $18.11 \pm 1.33$ & $7.65 \pm 0.46$ & $19.02 \pm 1.14$ & $107.74 \pm 1.02$ \\
60 & $36.27 \pm 1.44$ & $-5.56 \pm 0.37$ & $17.27 \pm 1.28$ & $8.42 \pm 0.51$ & $18.14 \pm 1.00$ & $107.84 \pm 1.01$ \\
80 & $33.47 \pm 1.76$ & $-5.18 \pm 0.26$ & $16.30 \pm 1.24$ & $11.36 \pm 0.68$ & $17.11 \pm 0.98$ & $107.62 \pm 1.11$ \\
100 & $32.45 \pm 1.63$ & $-4.83 \pm 0.15$ & $16.49 \pm 1.15$ & $12.25 \pm 0.71$ & $17.18 \pm 1.05$ & $106.31 \pm 0.96$ \\
120 & $32.30 \pm 1.14$ & $-4.18 \pm 0.24$ & $16.11 \pm 1.33$ & $12.68 \pm 0.58$ & $16.64 \pm 0.89$ & $104.56 \pm 0.87$ \\
\hline
\end{tabular}

As can be seen from this figures, the $\mathrm{L}$ value decreased with drying time, it changed from 43.37 to 32.30 . The "a" values changed from -7.22 to -4.18 as the drying time increased. Therefore, the colour of peppermint sample trend to lose its greenness when drying time increased. Instead, the $b$ value decreased at half of drying time. The initial and final $b$ values were 21.48 and 16.11, respectively. The change of colour may be due to decomposition of pigment compounds and non-enzymatic Maillard reaction [11]. As a whole, the total colour change $(\Delta \mathrm{E})$ of peppermint leaves increased during hot air drying and ranged from 4.10 to 12.68 as drying time increased.

Chroma and hue angle were calculated using equation (3)-(4). Results are shown in Table 3. The results showed that the values of hue angle, chroma decreased as a function of drying time. The hue angle value corresponds to whether the object is red, orange, yellow, green, blue, or violet. The initial hue angle of peppermint leaves was about $108^{\circ}$, which represents a colour in slightly green-predominantly yellow region of the colour solid dimensions (hue angle between $90-180^{\circ}$ ). Upon heating, the hue angle decreased, shifting towards the green region.

For the mathematical prediction of colour change of peppermint, zero-order and first-order models were used. It was observed that $L, a, \Delta E$ and hue angle values were fitted to the zero- 
order model, while $b$ and chroma were fitted to the first-order model. The estimated prediction parameters of these models and the statistical values coefficients of determination $\mathrm{R}^{2}$, adjusted $R^{2}$, as well as significant values $p$ are represented in Table 4 .

Table 4. Model summary, ANOVA and Coefficients of prediction model for colour changed.

\begin{tabular}{|c|c|c|c|c|c|c|c|}
\hline $\begin{array}{l}\text { Colour } \\
\text { Values }\end{array}$ & Model & Equation & $\mathbf{R}^{2}$ & Adjusted $\mathbf{R}^{2}$ & $\stackrel{p}{\mathbf{p}}$ & \multicolumn{2}{|c|}{$\underset{\text { (Coefficient) }}{\mathbf{p}}$} \\
\hline \multirow[b]{2}{*}{$\mathrm{L}$} & Zero-order & $40.354-0.75 t$ & 0.925 & 0.927 & 0.002 & $\begin{array}{l}\mathrm{t} \\
\mathrm{C}\end{array}$ & $\begin{array}{l}0.002 \\
0.000\end{array}$ \\
\hline & First-order & $40.592 * \exp (-0.002 t)$ & 0.933 & 0.916 & 0.002 & $\mathrm{t}$ & $\begin{array}{l}0.002 \\
0.000\end{array}$ \\
\hline \multirow{2}{*}{$\mathrm{a}$} & Zero-order & $-6.742+0.02 t$ & 0.982 & 0.978 & 0.000 & $\begin{array}{l}\mathrm{t} \\
\mathrm{C}\end{array}$ & $\begin{array}{l}0.000 \\
0.000\end{array}$ \\
\hline & First-order & No modeling & & & & $\begin{array}{l}\mathrm{t} \\
\mathrm{C} \\
\end{array}$ & \\
\hline \multirow[t]{2}{*}{ b } & Zero-order & $19.889-0.036 \mathrm{t}$ & 0.835 & 0.784 & 0.011 & $\begin{array}{l}t \\
C\end{array}$ & $\begin{array}{l}0.011 \\
0.000\end{array}$ \\
\hline & First-order & $19.957 * \exp (-0.002 t)$ & 0.850 & 0.813 & 0.009 & $\mathrm{t}$ & $\begin{array}{l}0.009 \\
0.009\end{array}$ \\
\hline \multirow{2}{*}{$\Delta E$} & Zero-order & $3.449+0.85 \mathrm{t}$ & 0.926 & 0.908 & 0.002 & $\begin{array}{l}\mathrm{t} \\
\mathrm{C}\end{array}$ & $\begin{array}{l}0.002 \\
0.021\end{array}$ \\
\hline & First-order & $4.220 * \exp (0.011 t)$ & 0.847 & 0.808 & 0.009 & $\mathrm{t}$ & $\begin{array}{l}0.009 \\
0.005\end{array}$ \\
\hline \multirow{2}{*}{ Chroma } & Zero-order & $20.897-0.04 t$ & 0.873 & 0.841 & 0.006 & $\begin{array}{l}\mathrm{t} \\
\mathrm{C}\end{array}$ & $\begin{array}{l}0.006 \\
0.000\end{array}$ \\
\hline & First-order & $21.083^{*} \exp (-0.002 t)$ & 0.890 & 0.860 & 0.005 & $\begin{array}{l}\mathrm{t} \\
\mathrm{C} \\
\end{array}$ & $\begin{array}{l}0.005 \\
0.000 \\
\end{array}$ \\
\hline \multirow{2}{*}{ Hue angle } & Zero-order & $108.986-0.029 t$ & 0.682 & 0.603 & 0.043 & $\begin{array}{l}\mathrm{t} \\
\mathrm{C}\end{array}$ & $\begin{array}{l}0.043 \\
0.000\end{array}$ \\
\hline & First-order & $109.011 * \exp (0.00 t)$ & 0.681 & 0.601 & 0.043 & $\begin{array}{c}\mathrm{t} \\
\mathrm{C}\end{array}$ & $\begin{array}{l}0.043 \\
0.000\end{array}$ \\
\hline
\end{tabular}

* C-Constant; * t -time

\section{CONCLUSION}

Results obtained from this research showed that qualities of dried peppermint are affected by temperature of hot air drying. It was observed generally that the decrease of essential oils content at high drying temperature is higher than at low temperature. The product which was dried at $50{ }^{\circ} \mathrm{C}$ was the most preferable. On the basis of the Hunter colour parameter $(L, a$ and $b)$ and colour sensory score, a model was constructed to predict the colour quality of dried peppermint. This model has a determination coefficient $\left(\mathrm{R}^{2}\right)$ of 0.976 , and a root mean square error of estimation (RMSE) of 0.24. Results obtained in this study showed that multivariate data analysis using the $L, a$ and $b$ values obtained by instrumental methods in combination with sensory scores can serve as a useful tool for colour quality prediction of dried peppermint. The colour change of peppermint leaves using the $\mathrm{L}$, $\mathrm{a}$ and $\mathrm{b}$ system totally explained the real behavior of peppermint samples undergoing hot air drying. The final values of $\mathrm{L}, \mathrm{a}, \mathrm{b}$ and total colour change $(\Delta \mathrm{E})$, chroma and hue angle were influenced by hot air drying. The zero-order and first-order models were used to explain the colour change kinetics and it was observed that L, a, 
$\Delta \mathrm{E}$ and hue angle values were fitted to the zero-order model, while $\mathrm{b}$ and chroma were fitted to the first-order model.

\section{REFERENCES}

1. Herro E. and Jacob S. E. - Mentha piperita (peppermint), Dermatitis 21 (6) (2010) 327-9.

2. Arslan D., Özcan M. M., and Mengeş H. O. - Evaluation of drying methods with respect to drying parameters, some nutritional and colour characteristics of peppermint (Mentha $\mathrm{x}$ piperita L.), Energy Conversion and Management 51 (12) (2010) 2769-2775.

3. Law C. L., Chen H. H. H., and Mujumdar A. S. - Food Technologies: Drying, in Encyclopedia of Food Safety, Y. Motarjemi, Editor, Academic Press: Waltham. (2014) 156-167.

4. Choudhury A. K. R. - Chapter 7 - Using instruments to quantify colour, in Principles of Colour and Appearance Measurement, A.K.R. Choudhury, Editor, Woodhead Publishing, 2014, pp. 270-317.

5. Koca N., Burdurlu H. S., and Karadeniz F. - Kinetics of colour changes in dehydrated carrots, Journal of Food Engineering 78 (2) (2007) 449-455.

6. Maskan M. - Kinetics of colour change of kiwifruits during hot air and microwave drying, Journal of Food Engineering 48 (2) (2001) 169-175.

7. Prachayawarakorn S., Saijai S., Supranee S., and Thitikorn P. - Kinetics of colour change during storage of dried garlic slices as affected by relative humidity and temperature, Journal of Food Engineering 62(1) (2004) p. 1-7.

8. Karanvir G., Rahul G., Suresh B., Manoj B. and Gurnaz G. - Effect of Hydro Distillation Process on Extraction Time and Oil Recovery at Various Moisture Contents From Mentha Leaves. Research Inventy: International Journal of Engineering And Science 4 (6) (2014) 8-12.

9. Cannon J. B., Charles L. C., Tess A., and Valtcho D. Z. - Modification of yield and composition of essential oils by distillation time. Industrial Crops and Products 41 (2013) 214-220.

10. Gavahian M., Asgar F., Reza F., Katayoun J., and Fakhri S. - Extraction of essential oils from Mentha piperita using advanced techniques: Microwave versus ohmic assisted hydrodistillation, Food and Bioproducts Processing 94 (2015) 50-58.

11. Rizzi G. P. - The Maillard Reaction in Foods, in Maillard Reactions in Chemistry, Food and Health, T.P. Labuza, et al., Editors, Woodhead Publishing, 2005, p. 11-19.

\section{TÓM TẮT}

\section{ẢNH HƯỞNG CỦA SÂYY KHÍ NÓNG LÊN HÀM LƯỢNG TINH DẦU VÀ ĐẶC TÍNH MÀU SẮC CỦA LÁ BẠC HÀ (Mentha piperita)}

Nguyễn Thị Yến Chi, Dương Thị Thanh Thảo, Hoàng Quốc Tuấn*

Viện Công nghệ sinh học - Công nghệ thưc phẩm, Truờng Đại học Bách khoa, Số 1 Đại Cồ Việt, Hà Nội, Việt Nam

"Email: tuanhqibft@gmail.com; tuan.hoangquoc@hust.edu.vn 
Mục tiêu chính của nghiên cứu này là đánh giá sự ảnh hưởng của nhiệt độ sấy trong phương pháp sấy khí nóng lên chất lượng của lá bạc hà bao gồm hàm lượng tinh dầu, thông số màu, chất lượng cảm quan màu và xây dựng mô hình động học biến đổi màu trong quá trình sấy. Thí nghiệm sấy được tiến hành ở năm mức nhiệt độ gồm $40,50,60,70$ và $80^{\circ} \mathrm{C}$. Thông số màu Hunter gồm 3 giá trị $L, a, b$ được sử dụng để xác định màu của lá bạc hà trong quá trình sấy. Các giá trị này cũng được sử đụng để tính toán giá trị của sự thay đổi màu tổng thể $(\Delta E)$, chỉ số nâu hóa, Chroma và Hue angle. Phép thử cảm quan thị hiếu trên 80 người được sử dụng để đánh giá chất lượng cảm quan màu của 05 mẫu lá bạc hà qua sấy. Kết quả cho thấy sự suy giảm hàm lượng tinh dầu của mẫu sấy ở nhiệt độ cao là cao hơn so với mẫu sấy ở nhiệt độ thấp. Phương trình hồi quy tương quan được sử dụng để xác định mối tương quan giữa điểm cảm quan thị hiếu màu và các giá trị màu. Kết quả cho thấy giá trị $\mathrm{L}$ và $b$ góp phần làm giảm giá trị cảm quan, còn giá trị a góp phần làm tăng giá trị cảm quan màu sắc của sản phẩm. Mô hình động học bậc 0 (zero-order) và bậc 1 (first-order) được sử dụng để dự báo sự thay đổi mầu của mẫu sấy ở $50^{\circ} \mathrm{C}$. Kết quả cho thấy mô hình bậc 0 có thể dùng để dự báo sự biến đổi của các chỉ số $L, a, \Delta E$ và hue angle, trong khi đó mô hình bậc 1 phù hợp cho sự biến đổi của hai chỉ số $b$ và chroma.

Tù khóa: lá bạc hà, màu sắc, mô hình động học biến đổi màu trong quá trình sấy. 